[Dette er en postprint/akseptert versjon av artikkelen, og ikke den endelige, publiserte versjonen. Enkelte endringer ble gjort før publisering.]

\title{
Nådens nærhet i 1300-tallets dominikanske ”søsterbøker”
}

Jon Flæten

F. 1981. Universitetsstipendiat ved Det teologiske fakultet, UiO. Adr: Det teologiske fakultet, Postboks 1023 Blindern, 0315 Oslo. E-post: j.o.flæten@teologi.uio.no

\begin{abstract}
The Dominican Sister-Books are collections of short vitae originating from the southern German Dominican women's convents in the early 14th century. This article discusses pious ideals and religious endeavors in the Sister-Books, focusing mainly on their asceticism and mysticism and visionary piety, and in light of German church historian Berndt Hamm's perspectives on patterns of pious behavior and 'near grace' in the late middle ages.
\end{abstract}

\section{Keywords}

\section{Sister-Books}

\section{Asceticism}

\section{Mysticism}

I de såkalte "søsterbøkene” (av Schwesternbücher, evt. Nonnenbücher) fra 1300-tallets sørtyske dominikanerinneklostre, finner vi samlet en rekke korte livsskildringer, vitae, fra disse klostrenes første generasjoner. Tekstene forteller om en slags "semi-helgener” fra miljøer hvor asketisk høyytelsesreligiøsitet ser ut til å ha spilt en stor rolle, og hvor sterke religiøse erfaringer, visjoner og religiøse transer fremstilles som en selvfølgelig del av et ideelt religiøst liv. Herfra fortelles det om nonner under sterk innflytelse som svever over bakken, som pisker og skjærer seg til blods, som synger og ler på dødsleiet. Her skal vi se at denne fromheten er knyttet til et grunntrekk ved senmiddelalderens religiøsitet, en intensivert "nådenærhet”. I sine analyser av senmiddelalderens fromhet har den tyske kirkehistorikeren Berndt Hamm rettet oppmerksomheten mot det han omtaler som en intensivert tilstedeværelse av det hellige og frelsende, av Guds "nære nåde”. Hamm viser også til nyskapende former for "medialisering” av denne nære nåden, ulike former for formidling av nåde, som alle var avledet av kristendommens grunnleggende nådehendelse ("Basismedialitet”), i Kristi lidelse og soningsverk (Hamm 2007; 2009). ${ }^{1}$ Via bilder og tekst, krusifikser og relikvier, sakramenter så vel som personlige visjoner 
og indre nærhetserfaringer, ble nådens kraft formidlet og gjort virkningsfull for og $i$ de troende. Nåden var innenfor rekkevidde; men det gjaldt også å gjøre seg mottagelig for denne nåden, oppfylle minimumskravene for innlevelse og slik gi et adekvat tilsvar til Guds barmhjertige henvendelse. Hva dette innebar kunne naturligvis forstås på ulikt vis, og gjøres med svært ulik grad av ytelse (sml. Hamm 2009). Ved hjelp av noen av Berndt Hamms perspektiver vil jeg i det følgende peke på hvordan "nådens nærhet” kommer til uttrykk og preger fromhetsidealene i de dominikanske søsterbøkene.

Det er rimelig å anta at disse nonnebøkene er produsert for å svare til et voksende behov for spesialisert fromhetslektyre innenfor en ny type religiøse institusjoner. Rundt år 1300 fantes det nesten 70 dominikanske kvinneklostre bare innenfor den sørtyske ordensprovinsen Teutonia. I ett kloster kunne det bo 80 til 100 nonner. Dels hadde disse klostrene vokst frem fra felleskap av beginer - fromme kvinner som hadde søkt sammen i små grupper for å realisere ”det apostoliske liv" 2 - som så igjen hadde blitt inkorporert i dominikanerordenen rundt midten av 1200-tallet. ${ }^{3}$ I Engelthal-bokens innledende klosterkrønike, forteller forfatteren Christine Ebner hvordan det hele begynte som en liten samling av beginer i Nürnberg som søkte seg mot dominikanerordenen for å kunne leve ”dag og natt i inderlighet”. ${ }^{4}$

Slike kvinneklostre var en lukket verden. Mens de mannlige dominikanerne hadde en omvandrende tigger- og prekenvirksomhet som sitt kjennetegn, levde nonnene under regelen om streng klausur, det vil si full atskillelse fra omverdenen. Flere av disse klostrene fikk etter hvert gode biblioteker og det ble mulig for fellesskapene å dokumentere sin egen forhistorie og produsere oppbyggelig litteratur beregnet på nye generasjoner i klosteret. ${ }^{5}$ Søsterbøkene er skrevet $a v$ kvinner for kvinner, om kvinner, noe som i seg selv er uvanlig i senmiddelalderen. ${ }^{6}$ Noen av forfatterne er kjente ved navn, som Elsbeth Stagel (Töss), Christine Ebner (Engelthal) og Anna von Munzigen (Adelhausen). Men bøkene er trolig også fellesprosjekter innad i de enkelte klostre, basert på miljøets felles erindring, og antagelig en blanding av muntlige og skriftlige anekdoter om nonnene fra disse klostrenes første tid, rundt midten av 1200-tallet (Lewis, ibid.; Bürkle 1999, 159f). Søsterbøkene gir et innblikk i denne unike livsformen, og kan fortelle oss hvordan kvinnelige spesialister i senmiddelalderen ønsket å fremstille et ideelt religiøst liv og hvordan de forsto sin egen streben.

Søsterbøkene fra dominikanerinneklostre som Töss, Engelthal, Adelhausen, Oetenbach, og Unterlinden er hovedsakelig samlinger av korte vitae, religiøse livsskildringer, men som religiøs oppbyggelse og undervisning for nye generasjoner i de samme klostrene (Bürkle 1999). Bøkene er for det meste skrevet og overlevert på middelhøytysk, og i enkelte tilfeller på latin (Unterlinden). En genrebetegnelse som tidlig ble tatt i bruk om denne typen tekster er Gnadenleben, "nådeliv”. Tekstene er skrevet etter mønster fra middelalderens populære helgenlegender. De har et nært slektskap til Vitae fratrum, ”Brødrenes liv”, legendesamlingen som forteller om de første dominikanerbrødrenes liv og virke, og som var fast lektyre kvinneklostrene (Lewis 1996, 51ff; Bürkle 1999). Som i Vitae fratrum finner vi også i noen av 
søsterbøkene genren klosterkrønike, idealiserende og nostalgiske legendefortellinger om de enkelte klostrenes opphav, om hvordan Gud utpekte stedet der klosteret skulle ligge og hvordan fellesskapet mirakuløst overlevde den første tiden i fattigdom og nød. Bøkene formidler en sterk felles identitet knyttet til det enkelte klostermiljø som "nådefellskap”. På tross av store likheter bøkene i mellom, og trolig litterær utveksling mellom klostrene, er det alltid ett enkelt fellesskap som skildres. Søsterbøkenes forfattere benytter en karateristisk "vi”-form, ("Vi hadde en salig søster som het...”) og formidler slik sitt miljøs felles erindring. Mens Vitae fratrum, beskriver et religiøst liv ”i verden”, er søsterbøkenes innhold fullt og helt preget av et liv omsluttet av klostermurene, og de reflekterer dermed klausurbestemmelsene for kvinneklostre. Bøkene er opptatt av indre anliggender, i dobbelt forstand: Det er "nådefellesskapets” indre dynamikk og de enkelte søstres indre liv og erfaringer med Gud som står i sentrum. Til forskjell fra den klassiske legendegenren, som gjerne er distansert og "objektiv” i formen, ser vi i søsterbøkene en subjektiv dreining, med stor vekt på hovedpersonenes følelsesliv og indre nådeerfaringer og henrykkelser. Søsterbøkene er eksponenter for en visjonær og mystisk orientert fromhet, hvor erfaringer av sterk sjelelig nærhet med Gud spiller en vesentlig rolle, som vi skal se. ${ }^{7}$ Søsterbøkene har lenge blitt ansett som del av "den tyske mystikken", og mer kjente mystikere som Mester Eckhart og Heinrich Seuse var med stor sikkerhet i kontakt med flere av disse miljøene (Sml Langer 1987; Burkle 1999). Også den sterke mystiske orienteringen er unik i forhold til den tidligere dominikanske legendetradisjonen. En betegnelse som tidlig ble tatt i bruk for å beskrive denne litteraturens blandingav legendestoff og mystikk, er Gnadenleben, "nådeliv” (Lewis ibid). ${ }^{8}$

\section{Mirakler og nådegaver}

Søsterbøkene gir uttrykk for en karismatisk fromhet. Det fortelles om en lang rekke små og store mirakler, tegn og personlige "nådegaver" (karismata, U 390) som blir søstrene til del (Lewis ibid., 76f). Spesielle nådegaver omtales gjerne som sunder genad, ”særskilt nåde”. Vi kan lese om søstre som blir omringet av sterkt lys (O 238; T 93). Slik fremstilles søstrene med glorier, en velkjent hagiografisk hellighetsmarkør (Lewis ibid., 85), samtidig som det antydes en indre "gjennomstråling” av nåde. Slike fenomener omtales gjerne som en "gave”. En mer spektakulær manifestasjon av Guds innflytelse finner vi i levitasjonen - å sveve over bakken. I Adelhausenboken fortelles det at søstrene kunne se Anna Turnerin sveve en halv favn over bakken (A 187). Fra Oetenbach fortelles det at en av søstrene "svevde som en fugl” (swirent als ein vogel) høyt over alle de andre i klosteret (O 269). Levitasjoner finnes det en rekke andre eksempler på i disse bøkene (A 160, 187; SK 126; T 32). Felles for disse eksemplene på levitasjon er at det er en dyp andakt og en sterk lengsel etter Gud, et begjær (begirde), som blir besvart med nådepåvirkning, og som gjør at søstrene svever.

Tårer og gråt er kanskje ikke like spektakulære mirakler, men blir nevnt gjennomgående når nonnenes eksemplariske hengivenhet skal beskrives. Kristi lidelse på korset ble sett på som en kjærlighetshendelse, og søstrenes tårer uttrykker en ideell holdning til lidelsen: compassio, 
"medfølelse”, og dermed et emosjonelt tilsvar til Guds kjærlighet. En av søstrene fra Töss, fortelles det, felte konstant dyptfølte tårer som gjorde at hennes ansikt alltid var hovent (T 36). Et annet sted i Töss-boken omtales denne særskilte nådegaven som minnetrechen, "kjærlighetstårer" (T 29). For også tårer beskrives som en gave fra oven. Ved hjelp av "tårenes gave” ble søstrene satt i stand til å sørge enda mer inngående over Kristi pasjon, slik den fortelles i evangeliet og slik som det var tilstede i klostrene i form av indre og ytre bilder, krusifikser og pieta-figurer (Lewis 1996: 81f; Ringler 1980: 219).

En annen type nådemanifestasjon som er nært forbundet med pasjonen, er stigmatiseringen, det å bli påført Jesu fem sårmerker. Dette fenomenet forbindes gjerne med Frans av Assisi og den legendariske hendelsen på La Verna-fjellet. Men det fortelles om stigmatisering hos en rekke andre mystikere og asketer i senmiddelalderen. ${ }^{9}$ I søsterbøkene finner vi flere eksempler på denne klassiske hellighetsmarkøren. I Töss-boken fortelles det at Mechthild fra Stans ble påført de fem sårmerkene (T 65), som her kalles ”kjærlighetstegn” (mine zaichen). Det fortelles at hun hadde vondt for å gå og å arbeide med hendene på grunn av disse sårene. En av de andre søstrene kunne se rett igjennom hennes sår da hun holdt hånden opp mot solen (T 65.24. sml. W 85). I søsterboken fra Weiler finnes eksempel på en litt annen type stigmatisering, "hjertesåret”, ferita (Gehring 1957, 217). En av søstrene fra dette klosteret ble mirakuløst påført et sår ved hjertet. Når hun stod i koret og sang, rant det "friskt blod" fra dette såret. Blodet ble samlet opp av noen andre søstre, og det fortelles at det holdt seg "rosefarget og velduftende” i lang tid. Det fortelles også at "lærde predikanter” (dvs. dominikanermunker) kom for å inspisere nonnens hjerte etter hennes død, og de kom frem til at dette hjertesåret var et "ekte tegn” (W 68, sml. 72). ${ }^{10}$

Som med "tårenes gave" handler det her spesifikt om en intens konsentrasjon mot Kristi lidelse, og en gjenskapning av pasjonen med nonnenes egne kropper som "medier". Fortellingen reflekterer senmiddelalderens intense opptatthet av detaljene i den grunnleggende nådehendelsen: Kristi blod og sår, og spesielt sidesåret, som i følge Johannesevangeliet ble åpnet av soldatens lanse da Kristus hang på korset (Joh. 19.34), hadde en spesiell status i middelalderens fromhet, og var gjenstand for inngående meditasjon. Åpningen av såret var et konkret og fortettet symbol på Guds kjærlighetsgjerning og henvendelse til menneskene (sml. Hamm, ibid. 28). Sidesåret ble sett på som en åpning mot Jesu indre, og en direkte vei til hans hjerte. Via såret formidles nåden; ut av såret strømmer Kristi blod, middelalderens religiøse "urstoff” (Angenendt), som søstrene søker å komme i nærest mulig forbindelse til. Med Weilernonnens hjertesår er forbindelsen til Kristus så nær at også hennes blod har blitt påvirket og forandret; det er friskt og velduftende, slik også Kristi blod gjerne beskrives i de samme tekstene. Fortellingen forsøker å formidle at en nær forbindelse til Kristus, og en nådens påvirkning, har renset hennes blod.

Fortellinger om slike nådegaver formidler et viktig budskap utover å være forbløffende underfortellinger. Undrene skjer ikke uten videre eller med hvem som helst; de er en tilnærming 
fra oven som svarer til en særlig innstilling og ytelse hos den enkelte søster. På mer eller mindre spektakulært vis virker nåden inn på kropp og sjel, som svar på en inngående meditasjon og konsentrasjon rettet mot lidelsen, et begirde etter å ta del i Guds nåde. ”Tårenes gave” kommer søstrene til unnsetning og gir den personlige andakten en ny kvalitet (sml. A 186f ; Hamm 2009, 46). Det interne og det eksterne inngår slik i en dynamisk relasjon som gjør at medlidenheten (compassio) justeres opp ett nivå, og det skapes ytterligere nærhet til lidelsen. Eksempelet med "hjertesåret” fra Weiler-boken legger vekt på at det er i koret, mens søsteren synger og deltar hengivent under messen, at det renner blod fra hennes mirakuløse sår. Berndt Hamm understreker at denne "tosidighetsrelasjonen" (evt. "tosidighetskontrakt” eller "kooperasjonsmodell”) preger den nære nåden i senmiddelalderen. Denne relasjonen er avgjørende for å forstå nådenærhetens mening og struktur (ibid., 46; sml. 2007). En grunnsetning som er bestemmende for senmiddelalderens teologi og religiøsitet er: "Gud vil ikke nekte sin nåde til den som gjør det som er i henne”. ${ }^{11}$ Slik fungerer nonnebøkene ikke bare som spektakulær underholdning, men også som oppbyggelige exempla som formidler et teologisk aksiom: De oppfordrer til hengivenhet til pasjonen og til personlig identifikasjon med Kristus i lidelsen, og de demonstrerer, her med mirakler som virkemiddel, hvordan Gud dermed kommer den fromme i møte.

\section{"Hellige øvelser" og blodmystikk}

Tilretteleggelse for Guds innflytelse skjer ved en særlig indre innstilling preget av lengsel, medlidenhet og meditasjon. Men nådeforberedelse skjer samtidig, og i betydelig grad, i form av ytre fromhetsmønstre og fromhetsøvelser. Søsterbøkene skildrer inngående og detaljert det strenge livet i klosteret, nonnenes utallige, dypt knelende bønner (venier), deres våkenetter og langvarige og ekstreme faste. Mest oppsiktsvekkende er de mange beskrivelsene av selvpisking og andre blodige fromhetsøvelser. Med søsterbøkenes piskescener kan vi snakke om en høyytelsesreligiøsitet, og en nokså ytterliggående fortolkning av den nevnte tosidighetskontrakten (Hamm, ibid). Anna von Klingau fra Töss gir en konsis formulering av søsterbøkenes lidelsesideal og deres fortolkning av middelalderens kooperasjonsmodell: ”Jo mer og jo villigere du lider, jo nærmere kommer Kristus” (T 37; Hamm 2009, 48).

Søsterbøkenes mange beskrivelser av sykdom - og visjoner og nådeerfaringer i forbindelse med sykdom - kan forklares i lys av denne "lidelsesfilosofi". ${ }^{12}$ Denne religiøsiteten preges av et kroppsideal som fremstår som svært fremmed for en moderne kultur: I middelalderens fromhet er den svekkede og skadde kroppen en ideell kropp (Dinzelbacher 2007, 11). Dette er fordi den svekkede kroppen er mer lik Kristi pinte og utmattede legeme, slik det fremstår i pasjonsfortellingen og i middelalderens mange gjengivelser av den. Lidelse, enten selvpåført eller ikke, fungerer nådeforberedende, siden det gjør at man nærmer seg Kristus.”Lid! Lid! Senk deres lidelse ned i Vår Herres sår!”, lyder en døende nonnes siste formaning i St.Katherinenthalboken (SK 153.24). 
Den vanligste variant av påført lidelse er selvpisking, som omtales med termen disciplin. I Töss-bokens innledning skildrer Elsbeth Stagel den utbredte selvpiskingen som fant sted klosteret: "Noen slo seg med jernlenker (yssnenen ketinen), noen med pisker (gaislen), noen med enebærbusker (rekoltren)" (T 14.21-22). Flagellasjonen i beskrives ofte i forlengelse av andre "hellige øvelser" (hailig uebunge), som bønn og faste. I blant kan piskingen ha et kollektivt og rituelt preg, og det kan også være forbundet med sang og liturgi (Largier 2007). Men de fleste og også de mest ekstreme tilfellene finnes som "soloprestasjoner", hvor det er den enkeltes utholdenhet og de blodige detaljene ved den selvpåførte lidelsen som understrekes. Beskrivelsene er overdrevene og sterkt stiliserte. De nevner gjerne at en søsters flagellasjon etterlot blodspor på bakken som de andre søstrene kunne se, altså en form for bevis for leserne (O 258). I Elsbeth von Villingens vita fra St. Katherinenthal leser vi:

Hun brukte pisken så ivrig hver natt og hver dag etter matins og etter complet, slik at blodet rant stritt nedover ryggen hennes som [...] andre søstre, som knelte ved henne, ble så overskyllet av blod fra hennes pisk at de måtte vaske sine drakter (SK 170.205f).

Caroline Bynum understreker at slike øvelser ikke primært var ment som ødeleggelse eller straff av det kroppslige, men at det må sees som Kristus-imitasjon (ibid. 131). ${ }^{13}$ Blodsutgytelse og søken etter renhet gjennom askese er helt sentral i disse bøkene. Å blø var et symbol på uttømming av kroppsvæsker og dermed renselse og soning, forklarer Bynum (ibid). Tilsvarende ble Kristi forsoningsverk i denne perioden fremstilt som den blodigste affære (ibid.). ${ }^{14}$ Mellom menneskets syndige blod og Kristi frelsende blod er det den største motsetning. Ved å åpne sine egne kropper og la blodet strømme, legges det til rette for mottagelse av nåden og effekten av Kristi "rosefargede blod”, som strømmer fra hans sår. ${ }^{15}$ Gjennom en lidelsesmystikk konsentrert rundt identifikasjon gjennom ytre lidelse, søker nonnene å oppnå nådens effekt. Den ytre likeformethet (conformitas) gjennom lidelse skaper en nær indre forbindelse. Kirkehistorikeren Arnold Angenedt har kommentert at Oetenbach-nonnen Elsbeth von Oye, i en passasje som er svært lik Elsbeth von Villingens piskescene ovenfor, uttrykker et ønske om at hennes eget blod skal blandes med frelserens blod (Angenendt 1994, 67).

Den selvpåførte lidelsen demonstrerer hvordan tradisjonelle fromhetsmønstre ble sterkt intensivert i senmiddelalderen, samtidig som den lidende Kristus, og lidelsens detaljer, ble stadig mer nærværende i form av indre og ytre bilder (Hamm, 2009). Asketiske øvelser hadde lenge vært en fast bestanddel i middelalderens klosterliv, et trekk ved den spesialiserte religiøsitet som går tilbake til de kristne ørkenfedrene, hvis legender (den såkalte Vitaspatrum) også ble lest jevnlig i disse kvinneklostrene (Ochsenbein ,1988). Mens den "klassiske” askesen anså en moderert kroppstukt som en vei til indre frihet og kontemplasjon, fant mange av senmiddelalderens helgener, asketer og mystikere den mest fullkomne form for kristusimitasjon i den selvpåførte lidelsen (Constable 1997, 219). ${ }^{16}$ Imidlertid kan vi også finne eksempler på at 
søsterbøkenes lidelsesfilosofi blir problematisert. Om Ita von Hohenfels fra Oetenbach fortelles det at hun hadde opplevd store anfektelser, frykt for djevelen og sterk tvil etter at hun hadde blitt enke (O 240). Hun vendte seg så om til et liv i "særlig strenghet” (sunderlicher strankheit), som inkluderte faste, bønn og disciplin. Selv ikke dette var tilstrekkelig for henne. Videre fortelles det at hun

... kuttet i seg selv med kniver (...) slik at kjøttet hang fra kroppen og blodet fløt slik fra henne at man kunne se blodsporene der hvor hun gikk; og enn så mye lidelse hun ga seg selv, så var hun allikevel helt helbredet den tredje dagen. Forstanderinnen forbød henne dette (240).

Fra de groteske detaljene ved en nonnes selvtortur slår fortellingen brått over i det som tydelig er en underberetning, om sårene som gror på tre dager. Dette viser hvordan legendegenren er fullt inkorporert i denne fortellermåten. Å slippe unna en livsfarlig hendelse er et typisk legendetrekk. Dermed poengteres det at slike øvelser kunne være livsfarlige. Her ser vi en selvtortur som går så langt at de overordnede i klosteret må gripe inn. Fortellingen viser hvordan en sterkt individualistisk religiøsitet kunne komme i konflikt med ordensreglene og autoritetene i klosteret, og dermed også med det sentrale lydighetsidealet (sml. T 14; Langer 1987: 146). Denne hendelsen fører til en interessant utvikling i fortellingen. Det fortelles videre at Ita von Hohenfels begynner å tvile sterkt på sin egen lidelsespraksis (O 240). Hun avslutter deretter sin selvtortur, og det fortelles også at hun gir slipp på sin egenvilje. Dermed åpenbarer Gud seg for henne og blir som en "levende ånd" i henne. Det heter videre at "kroppens og sjelens overnaturlige renhet," ikke kan fortjenes i dette livet, men er noe "...Gud gir av sin frie vilje," (O 244). Ita von Hohenfels' erkjennelse går ut på at den harde ytre lidelse i seg selv ikke gir den fullkommenheten hun søker (Langer 1987, 77ff). Selvpåført lidelse fører, i og for seg, ikke til den nødvendige indre renhet. Ita von Hohenfels oppdager viktigheten av å oppgi sin egenvilje for å oppnå en høyere form for religiøs selvrealisering (O 244). I stedet for den ytre askesen kommer en indre "viljesaskese", en viderekommen form for mystikk, som fører til en desto større nådenærhet: Gud blir som en levende ånd $i$ henne.

\section{Visjoner}

En vesentlig kanal for nådeformidling i søsterbøkene er de mange visjonene. Visjoner er i det hele tatt svært utbredt som litterær uttrykksform blant kvinnelige forfattere i middelalderen, noe som nok skyldes at de fleste andre genre var forbeholdt menn (sml. Haas, 1996, 195). For å igjen knytte an til Hamm, kan vi si at visjoner i søsterbøkene er eiendommelig et uttrykk for nådens ”medialisering” innenfor en mystisk fromhet senmiddelalderen (Hamm 2009).

Som de mange piskescenene følger også søsterbøkenes visjoner en rekke faste mønstre. Visjonene har gjerne utgangspunkt i bestemte steder og situasjoner i klosteret. I beskrivelser av visjoner og ekstaser er det ikke uvanlig at en søster opplever dette i sin seng forbindelse med 
sykdom og lidelse (leiden), og at denne tilstanden dermed fungerer erfaringsforberedende. Det finnes også en rekke nattlige "drømmevisjoner". ${ }^{17}$ Ekstaser og syner inntreffer ellers gjerne i koret i forbindelse med messefeiring, og dermed som følge av intens andakt og konsentrasjon over lidelsen. For eksempel kan en søster på et tidspunkt føler et sterkt begirde, begjær eller lengsel, etter Herren, og at denne lengselen så blir besvart ved at Han viser seg for henne som lidende på korset. Slike visjoner er det svært mange av, og det fremheves gjerne den visjonære tydelig kunne se Herrens "friske sår" og "rosefargede blod" (for eksempel W 72). Elsbeth Bechlin fra Töss opplever at Kristus stiger ned til henne fra krusifikset (T 88f). Det legges vekt på Kristi gegenwürtikeit (O 263), at han er fullt og helt tilstede, med sin kropp, sine sår, og sitt blod "akkurat slik han var" den dagen han ble korsfestet (A 184). En motsats til disse svært kroppslige visjonene av lidelsen og sårene er de mange visjoner av ulike lysfenomener. Slike forekommer gjerne om natten, mot en mørk bakgrunn (G 140; U 367; sml. T 57; Lewis 1996: 94f). Andre visjoner kan igjen forene begge disse uttrykksformene: Ita von Hutvil får ved en anledning se et lys stråle ut fra Herrens sår som er ”... så vakkert og så stort at hun ikke kunne sammenligne det med solen" (O 254). Bibelske fortellinger og bilder, legendariske konvensjoner og ikonografiske motiver ligger til grunn for innholdet i mange av visjonene. De aller fleste visjoner er sentrert rundt Kristus som menneske og knytter seg svært ofte til pasjonen (Lewis ibid.). Visjonene kan også fremstille møter med helgener, eller "syner" hvor klassiske motiver som lam eller trær står sentralt (Lewis ibid. 95f). ${ }^{18}$ I mange tilfeller er visjoner tydelig markert som en egen modus i teksten. Forfatterne kan understreke at det er snakk om "åndelig syn” (gaistlich gesicht), i motsetning til "legemlig syn" (liplich gesicht) (SK 131.68f). ${ }^{19}$ Visjonene kan være helt korte ”syner”, eller de kan involvere søsteren selv og utspille seg som lengre forløp og involvere hele sanseapparatet. I tillegg finnes også en rekke audisjoner, personlige åpenbaringer fra det guddommelige, og til og med dialoger mellom en søster og Herren. På denne måten kan det en søster tidligere har sett og opplevd i en visjon bli forklart og utlagt for henne i en senere åpenbaring. Dermed formidles nåden ikke bare som noe sansbart og kroppslig involverende, men også i form av erkjennelse og innsikt i de guddommelige mysterier.

Karakteristisk for disse bøkene er de mange visjonene av jesusbarnet. I Adelhausen-boken kan vi lese om en av søstrene som rundt juletider følte et sterkt begirde etter å se Vår Herre slik han var da han var nyfødt. Dermed viser Jesus seg for henne under messen som ”et skjønt, nyfødt barn.” Jesusbarnet kommer til henne og hun får sitte og holde det gjennom hele messen (A 170f; sml. T 88, SK 104). Fra Weiler-klosteret kommer en tilsvarende fortelling, hvor en av søstrene holdt jesusbarnet i fanget og lekte med det (W 72). Fra St. Katherinenthal fortelles det at en søster hadde fornemmelsen av slik nærhet til jesusbarnet at det var "som om hun var svanger med Vår Herre" (K 113). Jesusbarnvisjonene er eksempler på det Hester Gehring kalte "tredimensjonale" visjoner, som i større grad involverer berøringssansen en de rene "synene” (1957, 241f). Denne typen visjoner er karakteristiske for en kvinnelig, visjonær fromhet i denne perioden, og det skapes her egne rollemuligheter for kvinner i omgangen med det guddommelige (Bürkle 1999: 43ff). i slike visjoner spiller nonnene rollen som Jesu mor. Det er da ikke Christi, 
men imitatio Mariae-idealet, "Maria-imitasjonen”, som kommer til uttrykk (Dinzelbacher 2007, 92). Berøring og intim og fortrolig omgang med Jesusbarnet er nok et uttrykk for nådens nærhet, igjen foranlediget av den frommes sterke vilje og lengsel og intense deltagelse i messen.

En spesiell situasjon i klostertilværelsen som åpner for intens visjonær formidling, er døden og dødsleiet. Det fortelles om utallige nonner som får visjoner når de ligger på dødsleiet. Budskapet i slike visjoner er gjerne at den døende har gjort seg fortjent til direkte innpass i himmelen, og dermed ikke trenger å frykte renselsesoppholdet i skjærsilden. Visjoner som dette formidler et vesentlig budskap, nemlig at det ideelle "nådelivet” hadde forberedt den fromme på døden og den evige salighet. ${ }^{20}$ Livet i klosteret ble sett på som et liv i kontinuerlig dødsforberedelse; følgelig kan døden skildres som en slags feiring og befrielse. Visjonene på dødsleiet forsikrer nonnene om hva de har i vente, og dette gjør det mulig for dem å død en god og rolig død, uten frykt, noe som var et typisk tegn på hellighet. Johannes Døperen viser seg for søsteren Alhaid Ortlibin fra Nürnberg i hennes siste stund og formidler til henne: ”Jeg lar deg vite fra vår Herre Jesus Kristus at han har gitt deg forsikring om evig liv; der vil han gi deg all den lønn du har fortjent” (E 24.20f). "Etter dette,” forteller Christine Ebner, ”døde hun en riktig død.” Det fortelles om søstre som er blitt forsikret om sin frelse på denne måten og som ler og synger på dødsleiet (T 41f; E 8.28). Visjoner for de gjenlevende i etterkant av et dødsfall formidler til fellesskapet at den døende fikk en god utgang (Gehring 1957, 217). Søsterbøkenes dødsscener samler ikke bare klosterfellesskapet rundt sykesengen, men også himmelens engler og helgener møter opp for å føre den døendes sjel trygt inn i himmelen. ${ }^{21}$ Når en av nonnene i Weiler-boken dør, fortelles det at engler kommer med sang og stor fryd mens de jager vekk djevelen og maner hverandre: ”fly, alle, fly, vi kommer med en søster fra Weiler!” (W 85).

\section{Nattverden og den nære nåde}

Senmiddelalderens nådenærhet og det sofistikerte system for "medialisering” av nåden kan vi se i særlig grad i denne tidens teologiske og kirkelige styrking og utbygging av sakramentene som nådemidler, og da særlig nattverdssakramentet (sml. Hamm, 2009, 36). Nattverden var et omdreiningspunkt i senmiddelalderens religiøse liv, og i mange kvinnelige miljøer av den typen som søsterbøkene springer ut fra, er hengivenheten og interessen for nattverden særlig stor. I søsterbøkene er nattverden gjennomgående et utgangspunkt for visjonær erfaring. De omtalte jesusbarnvisjonene er ofte forbundet med nattverdsfeiringen. I bøkene fra Engelthal og Weiler finnes flere eksempler på at nonner rundt juletider får se oblaten i prestens hånd forvandle seg til et lite barn. ${ }^{22}$ Det nevnes at nonnene tydelig kunne se barnets armer og ben bevege på seg (W 80f; E 26.6-10; sml. D 19, SK 104f). ${ }^{23}$ Det nevnes også at dette skjer i forbindelse med elevasjonen, altså når presten sier innstiftelsesordene og holder hostien hevet. Andre steder blir det fortalt om nonner som kunne se et sterkt skinnende lys fra hostien, og den kan til og med vise seg som en fullvokst mann, som den "mann som den er" (SK 100). ${ }^{24}$ Disse "synene” legger vekt på nattverdshendelsen som en forvandling og Kristi nærvær i sakramentet. Siegfried Ringler har 
omtalt dette som uttrykk for en "narrativ teologi”, hvor læren om transsubstansiasjon og Kristi realpresens reflekteres i visjonær stil (Ringler 1990, 104). ${ }^{25}$ Men i mange av disse nattverdserfaringene demonstreres også en ambivalens i forhold til den sakramentale formidlingen. Mange av nattverdserfaringene viser en holdning hvor altersakramentet "kun” tjener som utgangspunkt for en indre, umiddelbar erfaring av nærhet. I Ita von Hutvils vita fortelles at hun ved en anledning kunne kjenne nattverdslegemet røre seg i munnen hennes, ”... som en liten fugl som slo med vingene” (O 248f). I etterkant får hun så en "hemmelig åpenbaring”, hvor denne hendelsen blir forklart for henne: Oblatens bevegelse i munnen, blir hun fortalt, svarer til den indre bevegelse og fryd hennes hjerte føler når hun forlater de ytre ting, glemmer seg selv, og går ”... videre opp i Herrens lidelse” (250). Her blir det tydelig at den egentlige hendelsen som søkes er en umiddelbar nærhet til Kristus. Dermed er det ikke lengre den sakramentale, prestlige formidlingen i og med nattverdselementene som står i sentrum. Det handler altså ikke primært om Kristi realpresens i sakramentet, som kirken formidlet og lærte, men om "den reelle erfaring”, den personlige, indre erfaringen av Guds nærvær, som sakramentet viser til og legger til rette for (Leppin 2001, 196). Å spise og drikke nattverdselementene, men også å se nattverden i forbindelse med elevasjonen, fungerer som anledninger til henrykkelse, som en katalysator for indre nådeerfaringer (K 106; Leppin ibid). Som Caroline Bynum har påpekt, forekommer nattverdsvisjoner og -mirakler av den typen vi har sett her nærmest utelukkende hos kvinner (Bynum 1991, 121ff). De personlige nattverdsvisjonene fra disse klostermiljøene har dermed også en interessant kjønnsdimensjon, siden de søker en umiddelbar nærhet som står i et visst spenningsforhold til den prestelige, og dermed utelukkende mannlige, formidlingen av nåde via sakramentene (sml. Hamm 2009, 48). Gjennomgående beskriver søsterbøkene for eksempel en praksis for ”åndelig kommunion”, eller ”begjærskommunion”, som var en etablert og akseptert form for "indre” nattverd i middelalderen, og som kunne finne sted dersom sakramentet ikke var tilgjengelig, for eksempel grunn av sykdom. Også dette er eksempler på nådeerfaringer og personlig kontakt med det guddommelige som går "utenom” den prestelig-sakramentale, hierarkiske nådeformidlingen. Adelheit von St. Gallen får i St.Katherinenthal-boken utdelt åndelig kommunion av Herren selv: Kristus skjærer av en bit av sin kropp og gir den til henne og sier "Dette er mitt legeme og blod” (SK 105). Disse kvinnelige mystikernes søken etter direkte kontakt kan dermed også gå "utenom hierarkiet”. Deres nattverdsfromhet står i slik en relativ uavhengighet til den mannlig styrte nådeformidlingen. Dette betyr ikke at en prestelig og kirkelig-hierarkisk nådeformidling nødvendigvis blir avvist, men at vi ser en forskjøvet betoning hvor den ytre dimensjonen relativiseres, mens den indre dimensjonen intensiveres (Leppin, ibid). Nattverden er én blant mange visjonære anledninger i en fromhetskultur som søker nye veier for å oppnå personlig og mest mulig umiddelbar erfaring av Guds nåde (Hamm, ibid.). 


\section{Mystisk enhet}

Nonnenes erfaringer av nådenærhet og Guds innvirkning på sjelen kan beskrives vagt, som en særlig "gjennomstrømming av nåde”, eller det kan antydes indirekte gjennom fenomener som levitasjon eller glorifisering. Men det finnes også inngående og detaljerte beskrivelser av sjelsforening med Gud, unio mystica. En slik forening eller umiddelbarhetserfaring kan også omtales som den særskilte nåden jubilus, eller som genad contemplativa. ${ }^{26}$ Søsterbøkenes forfattere understreker ofte at slike erfaringer egentlig er språkløse, at den nåde en søster mottok var så sterk "... at hun ikke kunne sette ord på det” (O 260). Erfaringene blir allikevel forsøkt satt ord på og fremstilt visuelt, som korte eller lengre visjonære og mystiske forløp.

Vitaet til Sophia von Klingnau i Töss-boken gir et interessant eksempel på denne litteraturens enhetsmystikk. Dette vitaet er nokså omfattende sammenlignet med et typisk vita i disse bøkene, og det bryter også med den vanlige kollektive fortellerformen. Töss-forfatteren, Elsbeth Stagel, skaper her en undervisningssituasjon hvor hun lar Sophia von Klingnau gjenfortelle for de andre søstrene om sine åndelige erfaringer (T 56ff). Sophia von Klingnau gjengir her en intens, mystisk erfaring hun har hatt. Hun forteller først om en smertefull tid hvor hun hadde følt at hun gjorde Gud vred og var i så store anfektelser at hennes hjerte var "nært ved å briste”. Hun hadde følt seg uverdig og at hun i Herrens øyne var "som en orm som kravlet langs bakken”. Hun føler seg syk og svekket, og når hun skal legge seg skjer det en dramatisk vending i fortellingen.

Da korset jeg meg og ville legge meg og hvile og leste verset: In manus tuas [Luk 23.46]. Og da jeg leste det, så jeg et lys komme fra himmelriket. Det var umåtelig skjønt og nydelig (...) Og i dette lyset og i denne fryd så jeg og skjønte jeg at min ånd [gaist] ble tatt ut av hjertet og ført ut gjennom munnen og høyt opp i luften; og da ble det gitt meg at jeg kunne se min sjel, ren og virkelig, med det åndelige syn, men med det legemlige syn kunne jeg ikke se noen ting (...) Og de undere jeg så og erkjente i henne [sjelen], det kunne intet menneske sette ord på (57.14-18)

Sophia von Klingnau oppgir sin egenvilje, uttrykt ved at hun leser verset In manus tuas... "I dine hender overgir jeg min ånd”. Et lys kommer mot henne, og hun blir selv trukket mot det og inn i det. I det som beskrives som en gave og en midlertidig evne, får Sophia se sin egen sjel, slik den virkelig er "i all sin prakt og skjønnhet”. Erfaringen fremstilles som et dødsforløp, en midlertidig, "mystisk død". ${ }^{27}$ Sophia får se sin sjel fly ut av kroppen gjennom munnen, slik middelaldermennesket forestilte seg at sjelen forlot kroppen i dødsøyeblikket. ${ }^{28}$ Fortellingen har et tydelig didaktisk preg og fungerer som undervisning om sjelens beskaffenhet, om det ”åndelige syn”, og om den saligheten som venter i himmelen. Det nevnes at de andre søstrene avbryter hennes fortelling og vil vite mer om hvordan sjelen virkelig er (57). Sophia forklarer for dem at hun så alt dette "med det åndelige syn”, og at det hun fikk se egentlig ikke kan beskrives 
med ord. "Sjelen”, forklarer hun, ”er en så åndelig ting at man ikke kan sammenligne den med noen legemlige ting.” Allikevel vil hun gi en sammenligning. ”Hun...”, det vil si sjelen,

... var et rundt og skjønt, gjennomlyst lys, lik solen, og var gullfarget rød, (...) og var alle stjernene på himmelen likeså sterke som solen, og var de alle samlet i én, kunne ikke dette skinn sammenlignes med den skjønnhet som var i min sjel, og jeg tenkte at det gikk en glans ut fra meg som lyste opp hele verden. (...) Og i dette lys, som var min sjel, så jeg Gud lyse vidunderlig som et vakkert lys som lyste fra en vakker lysende lykt, og jeg så at Han så kjærlig og med slik godhet føyde seg til min sjel at Han var helt forent med henne og hun med Ham. Og i denne kjærlige foreningen [ainbarung] ble min sjel forsikret av Gud at alle mine synder var tilgitt og renset bort, og at jeg var blitt så umåtelig ren som da jeg kom ut av dåpen (T 57.32-58.6)

Den mystiske erfaringen står i en særstilling når det gjelder nådens nærhet i søsterbøkene. Gud er ikke bare nær, men føyer seg til sjelen og de blir ett (unio mystica). For å forklare dette uforklarlige brukes en overflod av lysmetaforer. Dette billedspråket er typisk for søsterbøkenes "rene” enhetserfaringer. Det kroppslige billedspråket, preget av blod, tårer, sår etc., avtar i det sjelen forlater kroppen for å gå opp i den rene foreningen. ${ }^{29}$

Også i denne fortellingen danner lidelse og sykdom et grunnlag og fungerer som forberedelse for det videre avansementet. Fortellingen formidler et budskap som minner om det vi så i Ita von Hohenfels’ vita fra Oetenbach: Gud gir av sin frie vilje ”nådegaver” og føyer seg til sjelen, uavhengig av hvor syndige vi selv føler oss. Også her er oppgivelsen av egenviljen et sentralt, ”programmatisk” element. I denne opplyste henrykkelsen føyer Gud seg til sjelen i en "kjærlig forening”, og Sophia von Klingau opplever endatil å få en forsikring (58.4), direkte fra Gud, om at hennes synder er tilgitt, og at hun er blitt gjort så ren som da hun kom ut av dåpen. Igjen kan vi se en karakteristisk inderliggjøring av fromheten, også når det gjelder boten. Sophias fortelling antyder at en intens indre botsfromhet og syndserkjennelse har foranlediget erfaringen. I den opphøyde foreningen får hun så absolusjon - det avsluttende ledd i botssakramentet -, ikke formidlet via en prest, men som en direkte indre erkjennelse fra Gud.

Sophia von Klingnau blir her forespeilet sin egen frelse, i et øyeblikks henrykkelse. Men den sikkerhet hun erfarer, er forbigående, viser det videre forløpet i den samme fortellingen. Etter at foreningen er forbi svever hennes sjel tilbake og tar igjen bolig i kroppen, som i mellomtiden har ligget i sengen "som om hun var død” (58.28). Foreningen med Gud er altså forbigående, men den får sterke ringvirkninger. Erfaringen setter henne i en tilstand av "særlig nåde” som varer i åtte dager, hvor det er "en levende ånd” i henne, og hvor hun verken føler sult eller tørst eller tretthet (59.2-3). Deretter blir denne nåden brutalt rykket fra henne (59.16) og hun beskriver en hverdag preget av lengsel og "bitterhet”, og hvor hun også begynner å falle i tvil. Hun "betrakter” hendelsen i etterkant (59.17), og begynner å spørre seg hvordan Gud virkelig kunne ha gitt en så sterk nåde til et så syndig menneske som henne; hun begynner å frykte at det 
ikke hadde vært en ekte nådehendelse, men snarere et spill fra den bösen gaist, fra "den onde ånd". Gjennom samtalegitteret (redfenster), som var nonnenes kontakt med omverdenen, får hun til slutt høre at en verdslig person (ain usser mensch) hadde sett det samme lyset - hennes opplyste sjel - på himmelen over klosteret (59.24ff). Fra dette vitnet utenfra får hun dermed bekreftet at hennes erfaring hadde vært ekte.

Med sin psykologiske spennvidde og den inngående gjengivelsen av hovedpersonens egen erfaring, skiller dette vitaet seg ut fra den ellers knappe og repeterende stilen preger mange av disse tekstene. Sophia von Klingaus vita fremstår som en ansats til en religiøs selvbiografi, slik vi finner den fullt utviklet hos mystikere som Heinrich Seuse eller Theresa av Avila. Som oppbyggelig tekst, fungerer den som en undervisning om den ubeskrivelige salighet som venter $\mathrm{i}$ det hinsidige, og dermed som oppmuntring til videre religiøs bestrebelse. Men denne inngånde skildringen av de religiøsitetens ulike følelsesmessige stadier og tilstander viser også et annet vesentlig trekk: forbundet med søken etter nådens effekt er vi også det motsatte, fravceret av nåde, eller "unåde" (Ungnade), og den dertil assosierte frykten for djevelens overgrep (Hamm 2009; sml. 2007, 136). Den sikkerhet som oppnås er et øyeblikks sikkerhet, på erfaringsnivå. Deretter inntreffer hverdagen og tvilen. Sophias fortelling demonstrerer et annet viktig et poeng, som også i stor grad opptok senmiddelalderens teologer, nemlig at mystiske erfaringer og personlige åpenbaringer var usikre kilder (sml. Vauchez 2005, s 407ff). Teologenes respons på denne typen individualisert mystikk og visjonær fromhet, er i seg selv et interessant tema, men som det ikke er anledning til å drøfte i denne omgang.

\section{Avslutning}

Søsterbøkene blir til i en periode hvor formidlingen av Guds nåde fant nye veier og det oppstod nye kontaktflater for formidling og erfaring av hellighet. De dominikanske kvinneklostrene dannet en ny plattform for religiøs utøvelse. Fra eksemplene vi har sett her, kommer det fram en fromhet som i stor grad søker personlige, umiddelbare erfaringer av Guds nåde. En sterkt individualisert bestrebelse som kommer til uttrykk, har vi sett, kan komme i et visst spenningsforhold til ordenslivets øvrighet og til den institusjonaliserte sakramentsforvaltningen. Denne ambivalensen i forhold til sakramental nådeforvaltning er et typisk trekk ved en mystisk religiøsitet i senmiddelalderen (sml. Leppin 2001). Som vi har sett finnes det også i disse bøkene interessante antydninger til selvrefleksjon og indre spenning, både når det gjelder deres "lidelsesfilosofi" som vei til religiøst avansement, og de personlige erfaringers pålitelighet. Bøkene gir uttrykk for en grunnleggende modell for nådeformidling og -erfaring, og forsøker med sterke virkemidler og med legendens stiliserte fortellermåte å minne sine lesere om at nåden og frelsen er innenfor umiddelbar rekkevidde - for den som gjør de rette forberedelsene. 


\section{Bibliografi}

\section{Kilder}

A = Søsterboken fra Adelhausen: "Die Chronik der Anna von Munzingen. Nach der ältesten Abschrift mit Einleitung und Beilagen“ utg. J. König, Freiburger Diözesan Archiv 13 (1880).

E = Søsterboken fra Engelthal: Der Nonne von Engelthal Büchlein von der Genaden Uberlast, Literarischer Verein in Stuttgart. Utg. K. Schröder, Tübingen (1871).

$\mathrm{G}=$ Søsterboken fra Gotteszell: "Aufzeichnungen über das mystiche Leben der Nonnen von Kirchberg bei Sulz Predigerordens während des XIV. und XV. Jahrhunderts“, utg. F.W.E. Roth, Alemannia 21 (1893), 123-48.

$\mathrm{K}$ = Søsterboken fra Kirchberg: "Aufzeichnungen über das mystische Leben der Nonnen von Kirchberg bei Sulz Predigerordens während des XIV. und XV. Jahrhunderts“, utg. F.W.E. Roth, Alemannia 21 (1893), 104-23.

$\mathrm{O}$ = Søsterboken fra Oetenbach: ’Die Stiftung des Klosters Oetenbach und das Leber der seligen Schwestern daselbst, aus der Nürnberger Handschrift“, utg. H. Zeller-Werdmüller og Jacob Bächtold, Zurcher Taschenbuch 12 (1889).

Seuse, Vita = Heinrich Seuses tyske verker: K. Bihlmeyer, Heinrich Seuse. Deutsche Schriften im Auftrag der Würtembergischen Kommision für Landesgeschichte, Stuttgart (1961).

SK = Søsterboken fra St. Katharinenthal/Diesenhoff: Das 'St. Katherinenthaler Schwesternbuch'. Untersuchung. Edition. Kommentar, Meyer, R., Tübingen: Max Niemeyer Verlag (1995).

$\mathrm{T}$ = Søsterboken fra Töss: Das Leben der Schwestern zu Töss beschrieben von Elsbeth Stagel, samt der Vorrede des Johannes Meyer und dem Leben der Prinzessin Elisabeth von Ungarn, utg. F. Vetter, Deutsche Texte des Mittelalters Berlin (1907).

Vitae fratrum = Lives of the Brethren of the Order of Preachers 1206-1259. Translated by Placid Conway, O.P. Edited with notes and Introduction by Bede Jarrett, O.P. London: Blackfriars Publications (1955). Tilgjengelig på http://www.domcentral.org/trad/brethren/default.htm\#intro (11.01.2011).

W = Søsterboken fra Weiler: "Mystisches Leben in dem Dominikanerinnenkloster Weiler bei Eßlingen im 13. Und 14. Jahrhundert." Utg. K. Bihlmeyer, Würtembergische Vierteljahrshefte für Landesgeschichte 25 (1916). 


\section{Sekundærlitteratur}

Acklin-Zimmermann, B., 2000 ”Die Nonnenviten als Modell einer narrativen Theologie“. I: W. Haug / W. Schneider-Lastin (red.), Deutsche Mystik im abendländischen Zusammenhang. Neu erschlossene Texte, neue methodische Ansätze, neue theoretische Konzepte. (Tübingen: Max Niemeyer Verlag), 563-81.

Angenendt, A., 1994 Heilige und Reliquien. Die Geschichte ihres Kultes vom frühen Christentum bis zur Gegenwart (Munchen: Beck).

Blank, W., 1962, Die Nonnenviten des 14.Jahrhunderts. Eine Studie zur hagiographischen Literatur des Mittelalters unter besonderer Berücksichtigung der Visionen und ihrer Lichtphänomene (Freiburg im Br.).

Bonniwell, W. R., O. P., 1945, A History of the Dominican Liturgy 1215-1945 (New York: Joseph. F. Wagner, Inc.).

Browe, P., Die Eucharistie im Mittelalter. Liturgiehistorische Forschungen in kulturwissenschaftlicher Absicht. Utg. H. Lutterbach og T. Flammer (Münster: Lit Verlag).

Bürkle, S., 1999, Literatur im Kloster. Historische Funktion und rhetorische Legitimation frauenmystischer Texte des 14. Jahrhunderts (Tübingen: Francke Verlag).

Bynum, C. W., 1987 Holy Feast, Holy Fast. The Religious Significance of Food to Medieval Women (Berkley: University of California Press).

Bynum, C. W., 1991 Fragmentation and Redemption. Essays on Gender and the Human Body in Medieval Religion (New York: Zone Books).

Børresen, K. E., 1993 ”Women’s Studies of the Christian Tradition”, i Børresen og Vogt (red), Women’s Studies of the Christian and Islamic Traditions (London: Kluwer Academic Press), 13-129.

Constable, G., 1995 Three Studies in Medieval Religious and Social Thought. (Cambridge: Cambridge University Press).

Dinzelbacher, P., 1981Vision und Visionsliteratur im mittelalter (Stuttgart: Anton Hiersemann).

----- $\quad$ 1993, Mittelalterliche Frauenmystik (Paderborn: Ferdinand Schöningh)

------ 1998, Wörterbuch der Mystik (Stuttgart: Kröner verlag).

----- $\quad$ 2007, Körper und Frömmigkeit in der mittelalterlichenchkeit Mentalitätsgeschichte (Zürich: Ferdinand Schöningh). 
Fenten, S., 2007 Mystik und Körperlichkeit. Eine komplementär-vergleichende Lektüre von Heunrich Seuses geistlichen Schriften (Würzburg: Königshausen \& Neumann).

Gehring, H. R., 1957 The Language of Mysticism in South German Dominican Convent Chronicles of the Fourteenth Century. Avhandling. Univ. of Michigan (opptrykk av mikrofilm).

Goodich, M., 1981, “The Contours of Female Piety in Later Medieval Hagiography“, I: Church History, vol 50. 1. , 20-32.

Grundmann, H., 1961 Religiöse Bewegungen im Mittelalter. Untersuchungen über die geschichtlichen Zusammenhänge zwischen der Ketzerei, den Bettelorden und der religiösen Frauenbewegung im 12. und 13. Jahrhundert und über die geschichtlichen Grundlagen der deutschen Mystik (Georg Olms Verlagsbuchhandlung Hildesheim).

Hamm, B., 2009 ”Die Medialität der nahen Gnade im späten Mittelalter”. I: C. Dauven-van Knippenberg / C. Herberichs / C. Kiening, Medialität des Heils im Späten Mittelalter (Zürich: Chronos Verlag).

------- '”'Gott berühren”: Mystische Erfahrung im ausgehenden Mittelalter. Zugleich ein Beitrag zur Klärung des Mystikkbegriffs”. I: B. Hamm / V. Leppin, Gottes Nahe unmittelbar erfahren (Tübingen: Mohr Siebeck).

Haas, A. M., 1996 Kunst rechter Gelassenheit. Themen und Schwerpunkte von Heinrich Seuses Mystik (Bern: Peter Lang).

Kieckhefer, R., Unquiet Souls. Foruteenth-Century Saints and Their Religious Milieu. (Chicago: University of Chicago Press).

Largier, N., 2007 In Praise of the Whip. A Cultural History of Arousal, overs. G. Harman (New York: Zone Books).

Leppin, V., 2007 Die Christliche Mystik (München: Verlag C. H. Beck).

----- 2001 ”Mystische Frömmigkeit und sakramentale Heilsvermittlung im späten Mittelalter”, i Zeitschrift für Kirchengeschichte 112: 16.

Lewis, G. R., 1996 By Women, for Women, about Women. The Sister-Books of FourteenthCentury Germany (Toronto: Pontifical Institute of Medieval Studies).

McGinn, B., 2005 The Presence of God. A History of Western Christian Mysticism bd 4, The Harvest of Mysticism in Medieval Germany (New York: Crossroad).

Meyer, R., 1995 Das 'St. Katherinenthaler Schwesternbuch'. Untersuchung. Edition. Kommentar, (Tübingen: Max Niemeyer Verlag ). 
Ochsenbein, P., 1988 "Leidensmystik in dominikanischen Frauenklöstern des 14. Jahrhunderts am Beispiel der Elsbeth von Oye”. I: Dinzelbacher, P./Bauer, D. R., Religiöse Frauenbewegung und mystische Frömmigkeit im Mittelalter (Köln: Böhlau Verlag).

Peters, U., 1988, Religiöse Erfahrung als literarisches Faktum- Zur Vorgeschichte und Genese frauenmystischer Texte des 13. und 14. Jahrhunderts (Tubingen: Max Niemeyer Verlag).

Ringler, S., 1980 Viten- und Offenbarungsliteratur in Frauenklöstern des Mittelalters. Quellen und Studien (Munchen: Artemis Verlag).

------- 1990a, „Gnadenviten aus süddeutschen Frauenklöstern des 14. Jahrhunderts Vitenschreibung als mystische Lehre.“ I: D. Schmidtke (red.),”Minnichlichiu gotes erkennusse”. I: Studien zur frühen abenländischen Mystiktradition (Stuttgart: frommannholzboog), 89-105.

------- 1990b, ”Die Rezeption mittelalterlicher Frauenmystik als wissenschaftliches Problem, dargestellt am Werk der Christine Ebner.” I: Dinzelbacher / Bauer (red.), Frauenmystik im Mittelalter (Osfildern bei Stuttgart: Schwabenverlag), 178-200.

Rubin, M., 2002 (1991) Corpus Christi. The Eucharist in Late Medieval Culture (Cambridge: Cambridge University press).

Vauchez, A., 2005 Sainthood in the Later Middle Ages. Overs. J. Birrell, originaltittel La sainteté en Occident aux derniers sieclés du Moyen Age (1988) (Cambridge: Cambridge University Press).

Wehrli-Johns M., / Schneider-Lastin, W., 1999 „Zürich, Oetenbach“, I: Die Dominikaner und Dominikanerinnen in der Schweiz. Helvetia Sacra IV/5 bd I og II (Basel: Schwabe \& Co Ag), bd II, 1019-1036.

Winston-Allen, A., 2005 Convent Chronicles. Women Writing About Women and Reform in the Late Middle Ages (Pennsylvania: The Pennsylvania State University Press).

\section{Noter}

${ }^{1}$ Nåden, klargjør Hamm, er i bred forstand ”...die mit Gott identische und von Gott her kommende Kraft, die den Menschen zu seinem himmelschen Ziel der ewigen Herrlichkeit führt”, som altså “medialiseres” på ulike måter, i motsetning til frelsen, den himmelske salighet og gudsskuen (visio dei), hvor det ikke lenger finnes noen medialitet (2009, 22). 
2 Se art. 'Beginen/Begarden', TRE 5 (1980), 404ff. Sml. Dinzelbacher (2007), s. 225ff , som snakker om dette fenomenet som en "rollefornektelse" (Rollenverweigerung), i og med de mange kvinnene som aktivt valgte bort et tradisjonelt familieliv til fordel for en religiøs selvrealisering. Se også Herbert Grundmann (1935/1960), s. 319ff.

${ }^{3}$ En parallell utvikling finnes hos fransiskanerordenen, men i mindre skala. De eldre ordenene, som cistercienserne eller premonstrantenserne, hadde hatt kvinneklostre før dette, men stengte dels eller helt for inntak av flere kvinner i samme periode. Se Grundmann (1935/1961), 220ff; Lewis (1996), s. 6 og n. 17. Grundmanns studium har blitt stående som en av de aller beste gjennomgangene av de religiøse bevegelser i denne perioden. For noen innvendinger, blant annet mot termen "religiöse Frauenbewegung”, se Winston-Allen (2005), s 65f. Se også Dinzelbacher (ibid), s. 225ff .

${ }^{4}$ Denne klosterkrøniken i Engelthal-boken ble for Grundmann et typisk eksempel på overgangen fra beginefellesskap til ordenskloster i denne perioden (Grundmann, ibid). Sml. WinstonAllen (ibid.).

${ }^{5}$ For Oetenbach som eksempel på slike klostres biblioteker og litteraturproduksjon, se WehrliJohns / Schneider-Lastin (1999), s. 1029ff.

${ }^{6}$ Derav tittelen på Gertrud Jaron Lewis’ bok, By Women, for Women, about Women (1995), en av få helhetlige studier av denne tekstgruppen. Kari børresen minner om at de fleste kvinnelige asketers og mystikeres vitae ble redigert og dermed også "sensurert" av mannlige forfattere og skriftefedre $(1993,42)$. Disse nonnebøkene utgjør dermed et bemerkelsesverdig unntak. Selv om en viss redigering fant sted på 1400-tallet, se n.9 nedenfor, er tekstenes opprinnelse unik (Lewis, ibid., 56; 60). For andre studier av denne tekstgruppen, se Gehring (1957); Blank (1962), og i senere tid Peters (1988); Bürkle (1999); Winston-Allen (2005). De følgende avsnittene er i hovedsak basert på Lewis’ oversikt (1996). Med unntak av Ruth Meyers kritiske utgave av søsterboken fra St. Katharinenthal (1995), er trykte versjoner kun tilgjengelige i 1800- og tidlig 1900-talls utgivelser, ofte basert på enkeltmanuskripter.

${ }^{7}$ Sml. Volker Leppin, som forstår mystikk som ”...eine Ausprägung von Theologie oder Frömmigkeit, in deren mittelpunkt die innerweltlich proleptisch schon mögliche innerliche Wesens- oder Willenseinigung des gläubigen Menschen mit Gott steht. Diese Einigung kann Ausganspunkt des Denkens sein oder auch sein Zielpunkt. Innerhalb der spätmittelalterlichen Mystik sind als Idealtypen zu unterscheiden die spekulative Mystik und die devotionale Mystik” (2001, 190 n.5). Mystikk kan også helt enkelt beskrives som en "religiøs holdning” med gudsforeningen sentral komponent i fromhetslivet og i meditasjonen (sml. Leppin 2007). Se også Hamms ”bredere” forståelse av mystikk og 
mystikk-lignende fenomener som "personlig erfaring av Guds umiddelbare nærvær” (Hamm 2007, 135, og McGinn, samme sted n. 74). For diskusjoner knyttet til betegnelser som “Frauenmystik” eller “erfaringsmystikk”, og problemer knyttet til fortolkningen av tekster av kvinnelige visjonære og mystikere, se særlig S. Ringler (1990b), 178ff og P. Dinzelbacher (1994), 304ff., for to posisjoner. Se sammenfatning av diskusjonen og forskningshistorie for øvrig i Bürkle (ibid.).

${ }^{8}$ I tillegg til søsterbøkene finnes det også overlevert lengre "nådeliv” og ”åpenbaringer” knyttet til enkeltpersoner fra de samme klostrene. Se Ringler (1990a).

${ }^{9}$ For en god gjennomgang av fenomenet stigmata, se Constable (1995) s. 218ff ; se også Kieckhefer (1984) s. 94f.

${ }^{10}$ Det er typisk for søsterbøkene at når de en sjelden gang nevner mennesker "utenfra”, tjener disse til å bekrefte eller verifisere en eller annen nådefull hendelse i klosteret. Denne bemerkningen om predikantenes inspeksjon av søsterens ferita reflekterer også senmiddelalderens utfordringer forbundet med rapporterte nådemanifestasjoner og vurdering av deres ekthet. Om skepsis til stigmatiseringer i middelalderen, se Constable, $\mathrm{n}$. 14. For mer om middelalderkulturens evaluering av "besettelser” og mirakuløse hendelser med særlig vekt på kvinners rolle, se Nancy Caciolas bok Discerning Spirits. Divine and Demonic Possession in the Middle Ages (2003).

${ }^{11}$ Homini facienti quod in se est deus non denegat gratiam, er én formulering av dette konseptet. Se Hamm (2009), 46, og n. 60.

12 Uttrykket stammer fra Gehring (1957), s. 194. For mer om sykdom som motiv i denne litteraturen, se C. Bynum (ibid.), s. 131 og n. 44,

${ }^{13}$ Et kuriøst eksempel finner vi i Adelhausen-boken, hvor det fortelles det om søster Adelheit von Brisach, som var enke, og som i flere år klagde og sørget over sin syndighet og sin tapte jomfruelighet. I en visjon blir hun ført opp i luften av en engel og det blir gjennomført en ”åndelig blodoverføring”: Av engelen blir hun plassert i en vinpresse (trotten), hvor hun blir presset tom for alt sitt blod. Deretter får hun erstattet sitt tidligere, urene blod med jomfrulig, "friskt” blod (A 155). Om den mystiske vinpressen som symbol, se Rubin (2002), 313.

${ }^{14}$ Ferita-eksempelet nevnt ovenfor forsøker muligens å vise at nonnens blod har kommet i kontakt med, evt. byttet ut med, Kristi blod og blitt renset, og dermed velduftende. Et beslektet fenomen finnes hos Catharina av Sienna noen tiår senere, når hun i en ekstase får byttet ut sitt eget hjerte med Kristi hjerte. 
${ }^{15}$ Det er ikke bare sidesåret eller de fem sårene fra korsfestelsen som fremheves i senmiddelalderen, men også de utallige mindre sårene fra lidelsesforløpet. I følge Ludolf av Sachsens populære bok Vita Jesu Christi ble Jesus i pasjonen påført 5490 sår. Se Hamm (ibid)., s 44 og n. 21.

${ }^{16}$ Sml. Bynum (1991), 131; Se også Largier (2007).

${ }^{17}$ Drømmevisjoner ble i middelalderen sett på som en like gyldig formidler av guddommelig informasjon som visjoner og ekstaser som inntraff i våken tilstand. Se Haas (1996), s. 179.

${ }^{18}$ Det finnes også eksempler på visjonære reiser til de hinsidige straffesteder (O 240; A 186; U399), se Gehring (1957), 217, men dette er nærmest som korte ”innblikk” i skjærsilden sammenlignet med de lengre visjonære forløp som vi kjenner fra middelalderen, for eksempel hos Dante eller i Draumkvedet.

${ }^{19}$ Middelalderens teorier om visjoner går gjerne tilbake til Augustins tredeling, visio corporalis, visio spiritualis, og visio intellectualis (Dinzelbacher 1981, 83; Haas 1996, 186f).

${ }^{20}$ Se n. 1. over.

${ }^{21}$ En prototypisk dødsscene i middelalderens helgenlitteratur var Marias død, som reflekteres i flere av disse vitaene (Lewis 1996).

${ }^{22}$ Vi ser også at det visjonære innholdet korresponderer med kirkeåret. Tilsvarende er visjoner av lidelsen intensivert i forbindelse med påskefeiringen og erfaringer av ånden hyppigere rundt pinsen (Lewis 1996).

${ }^{23}$ For eksempler på jesusbarnvisjoner knyttet til nattverden hos andre kvinner i samme periode, se Bynum (1991), s. 130 og n. 39.

24 O 146; A 184; U 357; se Meyer (1995), s. 196; og Bynum (1991), s. 122f. For mer om natteverdsmirakler, se Peter Browe (2003), kap. II, ”Die Wundertätigkeit der Eucharistie”, ss. 211-291.

${ }^{25}$ Blant annet bygger dette på en viktig observasjon, nemlig at visjoner og åpenbaringer var blant de få litterære uttrykksformer som middelalderens samfunn tillot kvinner å benytte. De teologiske genrene, som traktatene, bibelkommentaren, prekenen, etc., var forbeholdt menn (ibid. 95f). Susanne Bürkle har innvendt mot dette at søsterbøkenes visjoner ikke bør sees som forsøk på å drive teologiske formidling til et større publikum, men heller som oppbyggelige og måltrettede exempla, beregnet på kvinner i en lukket klostertilværelse (Bürkle 1999, 43ff; Peters 1988, 38). 
${ }^{26}$ K 105, W 75, U353. Se også Leppin (2001.), s. 195f, og Lewis (1995), s. 49.

${ }^{27}$ Se art. ”Mors mystica” i Dinzelbacher (1998), s. 364f.

28 ”Sjel” og ”ånd” ser her ut til å være ensbetydende.

${ }^{29}$ For grundig gjennomgang av søstrenes visjonære og mystiske billedspråk, og særlig bruk av lysmetaforer, se Gehring (1957), 51ff og Blank (1962). 